\title{
Engineering inclusion bodies for non denaturing extraction of
} functional proteins

\author{
Špela Peternel ${ }^{* 1}$, Joze Grdadolnik², Vladka Gaberc-Porekar ${ }^{1}$ and \\ Radovan Komel ${ }^{1}$
}

Address: ${ }^{1}$ Department of Biosynthesis and Biotransformation, National Institute of Chemistry, Ljubljana, Slovenia and ${ }^{2}$ Department of Molecular Modeling and NMR Spectroscopy, National Institute of Chemistry, Ljubljana, Slovenia

Email: Špela Peternel* - spela.peternel@ki.si; Joze Grdadolnik - joze.grdadolnik@ki.si; Vladka Gaberc-Porekar - vladka.gaberc.porekar@ki.si; Radovan Komel - radovan.komel@ki.si

* Corresponding author

Published: I December 2008

Microbial Cell Factories 2008, 7:34 doi:10.1 I86/1475-2859-7-34
Received: 23 September 2008

Accepted: I December 2008

This article is available from: http://www.microbialcellfactories.com/content/7/l/34

(C) 2008 Peternel et al; licensee BioMed Central Ltd.

This is an Open Access article distributed under the terms of the Creative Commons Attribution License (http://creativecommons.org/licenses/by/2.0), which permits unrestricted use, distribution, and reproduction in any medium, provided the original work is properly cited.

\begin{abstract}
Background: For a long time IBs were considered to be inactive deposits of accumulated target proteins. In our previous studies, we discovered IBs containing a high percentage of correctly folded protein that can be extracted under non-denaturing conditions in biologically active form without applying any renaturation steps. In order to widen the concept of correctly folded protein inside IBs, G-CSF (granulocyte colony stimulating factor) and three additional proteins were chosen for this study: GFP (Green fluorescent protein), His7dN6TNF- $\alpha$ (Truncated form of Tumor necrosis factor $\alpha$ with an N-terminal histidine tag) and dNI9 LT- $\alpha$ (Truncated form of Lymphotoxin $\alpha$ ).
\end{abstract}

Results: Four structurally different proteins that accumulate in the bacterial cell in the form of IBs were studied, revealing that distribution of each target protein between the soluble fraction (cytoplasm) and insoluble fraction (IBs) depends on the nature of the target protein.

Irrespective of the folding pattern of each protein, spectroscopy studies have shown that proteins in IBs exhibit similar structural characteristics to the biologically active pure protein when produced at low temperature. In the case of the three studied proteins, G-CSF, His7 $\Delta$ N6TNF- $\alpha$, and GFP, a significant amount of protein could be extracted from IBs with $0.2 \% \mathrm{~N}$-lauroyl sarcosine (NLS) and the proteins retained biological activity although no renaturation procedure was applied.

Conclusion: This study shows that the presence of biologically active proteins inside IBs is more general than usually believed. A large amount of properly folded protein is trapped inside IBs prepared at lower temperatures. This protein can be released from IBs with mild detergents under non-denaturing conditions. Therefore, the active protein can be obtained from such IBs without any renaturation procedure. This is of great importance for the biopharmaceutical industry. Furthermore, such IBs composed of active proteins could also be used as pure nanoparticles in diagnostics, as biocatalysts in enzymatic processes, or even as biopharmaceuticals. 


\section{Background}

The formation of inclusion bodies (IBs) upon overexpression of heterologous proteins in Escherichia coli (E. coli) is a common event. Because of the belief that IBs are intracellular deposits of misfolded, biologically inactive proteins, they have been considered to be a bottleneck in protein production. To avoid time consuming and often unfavorable renaturation procedures, a lot of effort has been made to produce soluble proteins in bacteria either by altering the production process $[1,2]$, by co-expression of chaperones $[3,4]$ or by altering the target protein (point mutations, fusion proteins) $[5,6]$. In the last few years, the view of inclusion bodies has been changing. The first observations of enzymatic activity in proteins inside IBs $[7,8]$ were reported more than 15 years ago, but the phenomenon was not further explored and the usefulness and biotechnological importance were not recognized. Recently, several groups have reported the presence of biologically active proteins inside IBs [9-12]. The presence of residual native-like structures detected by Fourier transform infrared (FT-IR) spectroscopy has been reported by several authors $[13,14]$.

Previous studies in our laboratory revealed an interesting type of inclusion bodies containing a high percentage of correctly folded protein precursor trapped inside (nonclassical IBs - ncIBs). For fermenter cultivation, Jevsevar at al. [12] reported more than $40 \%$ activity of granulocyte colony stimulating factor (G-CSF) extracted from ncIBs under non-denaturing conditions, whereas in the shake flask culture the percentage of biologically active G-CSF was even higher [11]. Therefore the research was expanded to other structurally unrelated proteins that all form inclusion bodies upon overexpression in E. coli. In addition to human granulocyte colony stimulating factor (G-CSF), green fluorescent protein (GFP), N-truncated form of tumor necrosis factor $\alpha$ bearing an $\mathrm{N}$-terminal histidine tag (His7 $\Delta$ N6TNF- $\alpha$ ), and N-truncated form of Lymphotoxin $\alpha(\Delta$ N19LT- $\alpha)$ were studied.

As was previously already reported for diverse proteins by several authors [12,15-17] we also demonstrate that the production of IBs at low temperature results in a higher amount of correctly folded proteins trapped inside IBs. This work is aimed at exploring whether the amount of correctly folded protein trapped in IBs is protein specific. Increased solubility in low concentration detergents was also studied. Solubility of inclusion bodies in mild detergents under non-denaturing conditions enables the extraction of the target protein in biologically active form without any denaturation and renaturation process. This is an interesting, and for downstream processes very important, property.

\section{Methods \\ Strains and plasmids}

Recombinant E. coli production strain BL21(DE3) (Novagen) was used in this study along with expression plasmids pET3a, pET19b (Novagen), and pQT2 (Qiagen) coding four structurally different proteins.

Details about the production of the BL21(DE3) [pET3a/PFopt5] strain for G-CSF production were described by Jevsevar et al. [12].

Human lymphotoxin alpha (LT $\alpha$ ) from plasmid BBG 5 (R\&D Systems) was amplified and truncated by PCR. The truncated form of LT $\alpha$ (lacking the first 19 amino acids: $\mathrm{M}^{1} \mathrm{LPGVGLTPSAAQTARQHPK}^{20}$ ) was subcloned into the pET19b plasmid (Novagen) between the NdeI and BspHI restriction sites. Plasmid pET19b-dN19 LT- $\alpha$ was then transformed into the E. coli BL21(DE3) production strain.

Synthetic human tumor necrosis factor alpha (TNF $\alpha$ ) with $E$. coli optimized codons was obtained from British Biotechnology. The N-terminus was truncated (deletion of the first six amino acids: $\mathrm{V}^{1} \mathrm{RSSSR}^{6}$ ) and amplified by PCR. The deleted protein was than subcloned into the pQE-TAGZyme-2 plasmid (pQT2 - Qiagen), which encodes for the His 7 affinity tag, between the restriction sites SphI and HindIII [18]. Plasmid pQT2-dN6 TNF $\alpha$ was then transformed into the E. coli BL21(DE3) production strain.

Green fluorescent protein (GFP) from plasmid pGFP (Clontech) was amplified by PCR and subcloned into the pET19b plasmid between the restriction sites XhoI and NcoI. Plasmid pET19b-GFP was then transformed into the E. coli BL21(DE3) production strain.

\section{Medium}

LBG/amp 100 medium: 10 g/l BBL Phytone Peptone (Becton Dickinson), $5 \mathrm{~g} / \mathrm{l}$ Bacto Yeast extract (Becton Dickinson), $10 \mathrm{~g} / \mathrm{l} \mathrm{NaCl}$ (Sigma), $100 \mathrm{mg} / \mathrm{l}$ ampicillin (Sigma), and $2.5 \mathrm{~g} /$ l glucose (Sigma).

GYSP/amp 100 medium: 20 g/l BBL Phytone Peptone (Becton Dickinson), $5 \mathrm{~g} / \mathrm{l}$ Bacto Yeast extract (Becton Dickinson), $10 \mathrm{~g} / \mathrm{l} \mathrm{NaCl}$ (Sigma), $10 \mathrm{~g} / \mathrm{l}$ glucose (Sigma), trace elements $\left(\mathrm{FeSO}_{4} 7 \mathrm{H}_{2} \mathrm{O}(40 \mathrm{mg} / \mathrm{l}), \mathrm{CaCl}_{2} 2 \mathrm{H}_{2} \mathrm{O}(40\right.$ $\mathrm{mg} / \mathrm{l}), \mathrm{MnSO}_{4} \mathrm{nH}_{2} \mathrm{O}(10 \mathrm{mg} / \mathrm{l}), \mathrm{AlCl}_{3} 6 \mathrm{H}_{2} \mathrm{O}(10 \mathrm{mg} / \mathrm{l})$, $\mathrm{CoCl}_{2} 6 \mathrm{H}_{2} \mathrm{O}(4 \mathrm{mg} / \mathrm{l}), \mathrm{ZnSO}_{4} 7 \mathrm{H}_{2} \mathrm{O} \quad(2 \mathrm{mg} / \mathrm{l})$, $\mathrm{NMoO}_{4} 2 \mathrm{H}_{2} \mathrm{O}(2 \mathrm{mg} / \mathrm{l}), \mathrm{CuSO}_{4} 5 \mathrm{H}_{2} \mathrm{O} \quad(1 \mathrm{mg} / \mathrm{l})$, $\left.\mathrm{H}_{3} \mathrm{BO}_{3}(0.5 \mathrm{mg} / \mathrm{l})\right)$, and $100 \mathrm{mg} / \mathrm{l}$ ampicillin (Sigma).

Inducer: 0.4 mM IPTG (Sigma). 


\section{Culture conditions}

Initial bacterial inoculum was prepared in a shake flask culture and grown overnight at $25^{\circ} \mathrm{C}$ at $160 \mathrm{rpm}$ on the LBG/amp 100 medium. It was then transferred to the GYSP/amp 100 medium and induced with IPTG (immediate induction). The shake flask cultures were incubated at $160 \mathrm{rpm}$ and $25^{\circ} \mathrm{C}, 37^{\circ} \mathrm{C}$, and $42^{\circ} \mathrm{C}$ independently (Kühner linear shaker) until the culture reached the stationary phase. After production, the biomass was aliquoted, centrifuged, and the supernatant was discarded. The bacterial pellet was stored for further analysis.

\section{Isolation of inclusion bodies}

The bacterial pellet was resuspended in $50 \mathrm{mM}$ Tris/ $\mathrm{HCl}$, containing $30 \mathrm{mM} \mathrm{NaCl}$. The high-pressure homogenizer Emulsiflex $^{\circledR}$ - C5 (Avestin) was used for cell disruption (operating pressure 75 - $100 \mathrm{MPa}$ ); several passages were made. The homogenate was centrifuged at 10,000 g. The supernatant (soluble protein fraction; SN1) was stored for analysis. The pellet of IBs (P1) was washed twice with pure water and used for further analysis.

Distribution of target protein between cytoplasm and IBs The bacterial pellet, separated cell fractions after cell disruption ( $\mathrm{SN} 1, \mathrm{P} 1)$, and samples gathered after extraction of target protein from IBs (SN2, P2) were analyzed by SDS-PAGE. Gels were analyzed densitometrically with a ProExpress Imaging System (Perkin Elmer).

\section{Infrared analysis}

The proteins were prepared in a solution, as highly hydrated ammonium sulfate precipitate and as IBs prepared at three various growth temperatures $(25,37$, $42^{\circ} \mathrm{C}$ ). Washed IBs, as well as ammonium sulfate precipitates, were dried in a Savant DNA Speed-Vac system for one-hour prior to analysis to reduce water interference in the infrared spectra. The infrared spectra of protein samples were recorded on a Bruker IFS66S spectrometer equipped with liquid nitrogen cooled MTC detector and Golden-Gate ATR diamond cell. The infrared spectra were used mainly for monitoring the deviations in structures of proteins prepared at different temperatures with respect to properly folded ones. Therefore, the effects of reflection were neglected and the ATR spectra were used as recorded with no additional corrections. Typically, 64 scans were averaged at a resolution of $4 \mathrm{~cm}^{-1}$ and apodized with a triangular function. Solvent spectra were recorded and subtracted before the examination of the amide I bands. The structures of the amide I and amide II regions were analyzed by second derivatives and Fourier deconvolution. The derivative spectra were smoothed by the Savitzky_Golay algorithm applying the $3^{\text {rd }}$ polynomial and 15 smoothing points and normalized on the Tyrosine band near $1517 \mathrm{~cm}^{-1}$. The spectra were processed applying the Grams software package.

\section{Extractability of inclusion bodies}

The wet IBs pellet (P1) was resuspended with solubilizing buffer (40 mM Tris/HCl with $0.2 \%$ N-lauroyl sarcosine, $\mathrm{pH} 8.0$ ) at a ratio of 1:40. The suspension was shaken for 24 hours at $20^{\circ} \mathrm{C}$ and centrifuged at $4400 \mathrm{~g}$ for $15 \mathrm{~min}$ utes. The supernatant (solubilized target protein from IBs; SN2) and pellet (insoluble fraction of IBs; P2), as well as the supernatant SN1 and pellet P1 (chapter 2.2 Preparation of washed inclusion bodies) were analyzed by SDSPAGE. The target protein was determined densitometrically as a fraction of the total proteins by profile analysis using a BIO-RAD imaging densitometer - model GS-670. Supernatants were further used for biological activity measurements.

\section{Biological activity}

The biological activity of G-CSF was measured via proliferation activity on the murine myeloblastic NFS-60 cell line [19].

The biological activity of TNF $\alpha$ and LT $\alpha$ was measured via the specific cytotoxic activity on the mouse fibroblast L929 cell line $[20,21]$.

The biological activity of all proteins was measured in two distinctive fractions: in the supernatant (soluble protein produced in the cytoplasm; SN1) and in IBs solubilized with $0.2 \% \mathrm{~N}$-lauroyl sarcosine (SN2). All the samples were filtered through $0.22 \mu \mathrm{m}$ centrifuge cellulose acetate filters (Costar SPIN-X ${ }^{\mathrm{TM}}$ ) before testing. Average specific activity of the proteins inside the cell fraction is presented as the result.

\section{Fluorescence}

In the case of GFP, fluorescence was taken as a sign of a correctly folded and oxidized protein. The fluorescence spectrum of GFP soluble in the cytoplasm (SN1) as well as of GFP extracted from IBs (SN2) was compared to the spectrum of an in-house GFP standard isolated and purified in our laboratory.

The fluorescence of soluble GFP and GFP extracted from IBs with $0.2 \% \mathrm{~N}$-lauroyl sarcosine (SN2) was measured on a QuantaMaster C-61 Spectrofluorometer (Photone Technology International).

\section{Results and Discussion}

Distribution of target protein between cytoplasm and IBs The protein yield of all four proteins, G-CSF, GFP, His7 $\Delta$ N6TNF- $\alpha$, and $\Delta$ N19LT- $\alpha$, was relatively high, as target proteins represent $35-45 \%$ of total cell proteins (Table 1). All four proteins form inclusion bodies, but the distribution of the target protein between the soluble form in the cytoplasm and the aggregated form of IBs depends on the protein. 
Table I: Protein yield of target proteins inside bacterial cells is presented, as well as the distribution of target protein between soluble and insoluble cell fraction.

\begin{tabular}{ccc}
\hline Target protein & \% of target protein in total proteins (protein yield) & \% of protein in insoluble fraction (IBs) with respect to total target protein \\
\hline G-CSF & 38 & 98 \\
GFP & 45 & 77 \\
His7dN6TNF- $\alpha$ & 39 & 40 \\
dNI9LT- $\alpha$ & 35 & 91 \\
\hline
\end{tabular}

Many environmental factors influence the formation of IBs but predicting whether the target protein will accumulate as a soluble or insoluble fraction in the cell is still almost impossible, since this is dependent on the polypeptide and its sequence [22]. Even changing only one amino acid in the polypeptide sequence can drive a formerly soluble protein to aggregate in the IBs [23].

In the case of G-CSF, almost all protein is found in IBs. As already reported, the amount of correctly folded protein inside the IBs strongly depends on the growth temperature [12], with growth at a low temperature of $25^{\circ} \mathrm{C}$ resulting into the highest percentage of correctly folded protein.

In contrast, at low growth temperatures, fluorescent GFP (correctly folded and oxidized) was found to be soluble to a large extent in the E. coli cytoplasm (data not shown). However, using a bacterial host with a strong promoter, it was possible to force the formation of fluorescent IBs.

Although native trimeric TNF- $\alpha$ is produced well as soluble product in E. coli cytoplasm [20], the addition of a histidine affinity tag to the truncated form of TNF- $\alpha$ (His7 $\Delta$ N6 TNF- $\alpha$ ) causes some formation of IBs. However, the majority of the protein still remains soluble in cytoplasm.

On the other hand native LT- $\alpha$, also known as TNF- $\beta$, is a trimeric cytokine very similar to TNF- $\alpha$, but appears in both soluble and IBs form (data not shown), while the truncated form (dN19 LT- $\alpha$ ) occurs predominantly as insoluble IBs (Table 1).

\section{Infrared studies}

The secondary structures of the proteins inside IBs were examined by infrared spectroscopy. The frequency and the shape of the amide I bands in the spectral region between 1690 and $1620 \mathrm{~cm}^{-1}$ are sensitive to different types of protein secondary structure [24]. A band analysis of the amide I region, retrieves accurate information about protein secondary structure [25]. However, the components of the amide I band, which belong to different secondary structure elements, are strongly overlapped. To extract these components, second derivatives and Fourier decon- volution were applied. Both mathematical approaches give an almost identical intrinsic band structure in the amide I region, so solely the results of the second derivates are presented.

The presence of a large amount of correctly folded hG-CSF protein inside IBs prepared at low temperature was confirmed by infrared spectroscopy [12]. At higher temperatures $\left(37^{\circ} \mathrm{C}, 42^{\circ} \mathrm{C}\right)$, the infrared spectra of IBs revealed red shifts of the maxima and different shapes pointing to different structures and intermolecular associations of proteins inside the IBs.

Although the protein folding of G-CSF is completely different from GFP, His7 $\Delta$ N6TNF- $\alpha$ or $\Delta$ N19LT- $\alpha$, even for these proteins the highest amount of correctly folded structure inside the IBs was found when the bacterium growth was performed at relatively low temperatures. Infrared spectra of highly purified GFP and His7 $\triangle$ NGTNF$\alpha$ protein solutions, as well as of ammonium sulfate precipitates (ASP) of the pure proteins, were recorded and compared to the infrared spectra of isolated IBs prepared at different cultivation temperatures. ASP represents the correctly folded solid form of the pure protein as was proven by biological activity measurements after precipitate dissolution [12].

As pure GFP in solution tends to aggregate at high concentrations, the IBs samples were compared to the ASP of pure GFP (Figure 1). The second derivative spectra in the amide I and amide II regions are presented in Figure 2. The distinctive bands characteristic for $\beta$-structure $[26,27]$ can be found at $1627 \mathrm{~cm}^{-1}$ and $1686 \mathrm{~cm}^{-1}$. The original, as well as the secondary derivative spectra of IBs prepared at $25^{\circ} \mathrm{C}$ and $37^{\circ} \mathrm{C}$ are very similar to the spectrum of the pure protein. In contrast, the spectrum of the IBs prepared at $42^{\circ} \mathrm{C}$ possesses several differences. The most pronounced one is the decrease in the intensity of the band at $1627 \mathrm{~cm}^{-1}$ while the intensity of the band at $1650 \mathrm{~cm}^{-1}$, characteristic for unordered protein structure [26], increases.

The structure and frequencies of band components of the amide I region in the infrared spectrum of pure His $7 \Delta \mathrm{N} 6$ TNF- $\alpha$ confirmed the predominantly $\beta$ structure of the 


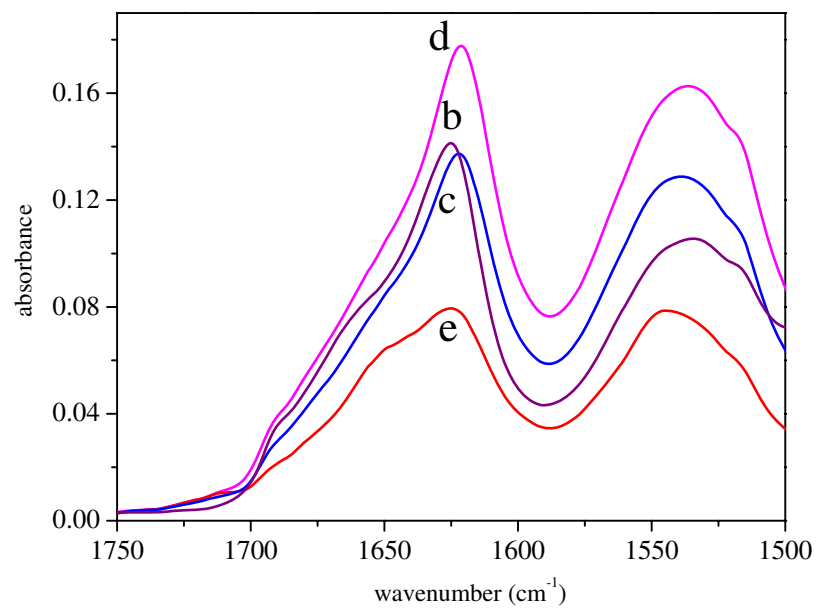

Figure I

FT-IR spectra in Amide I and Amide II regions of ammonium sulfate precipitate of pure GFP (b), and inclusion bodies isolated from $E$. coli incubated at different temperatures: $25^{\circ} \mathrm{C}$ (c), $37^{\circ} \mathrm{C}(\mathrm{d})$ and $42^{\circ} \mathrm{C}(\mathrm{e})$.

protein (Figure 3 and Figure 4). The bands of the ASP of the pure protein moves slightly towards the $1620 \mathrm{~cm}^{-1}$ characteristic for intermolecular $\beta$-sheet connections [28]. Upon resuspension, the ASP biological activity of the protein remains unchanged (data not shown), thus no change in the protein structure is expected to occur in ASP. IBs prepared at $37^{\circ} \mathrm{C}$ show the same spectrum as the ASP, while the spectra of the IBs prepared at $25^{\circ} \mathrm{C}$ and $42^{\circ} \mathrm{C}$ have an additional band at $1650 \mathrm{~cm}^{-1}$ characteristic for unordered protein structure [26].

For $\Delta \mathrm{N} 19 \mathrm{LT}-\alpha$, only spectra of IBs prepared at different temperatures were recorded since the protein is very

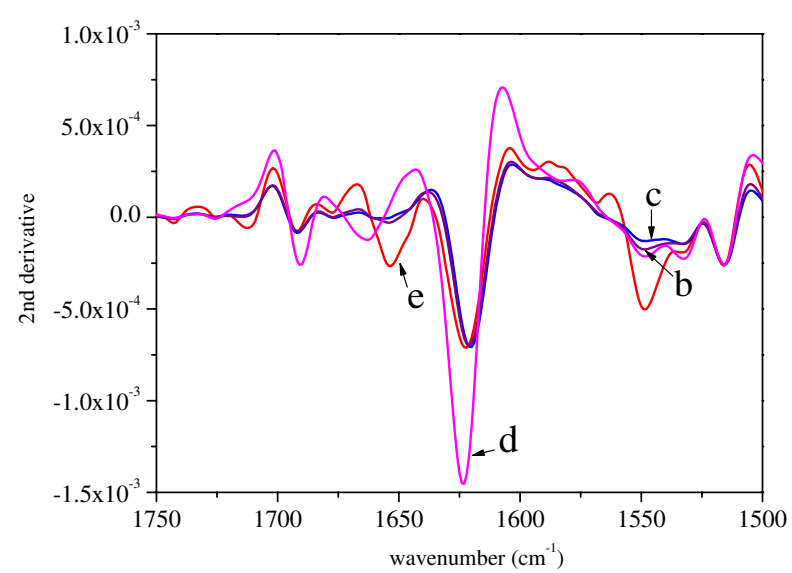

Figure 2

The second derivatives of the spectra presented in Figure I.

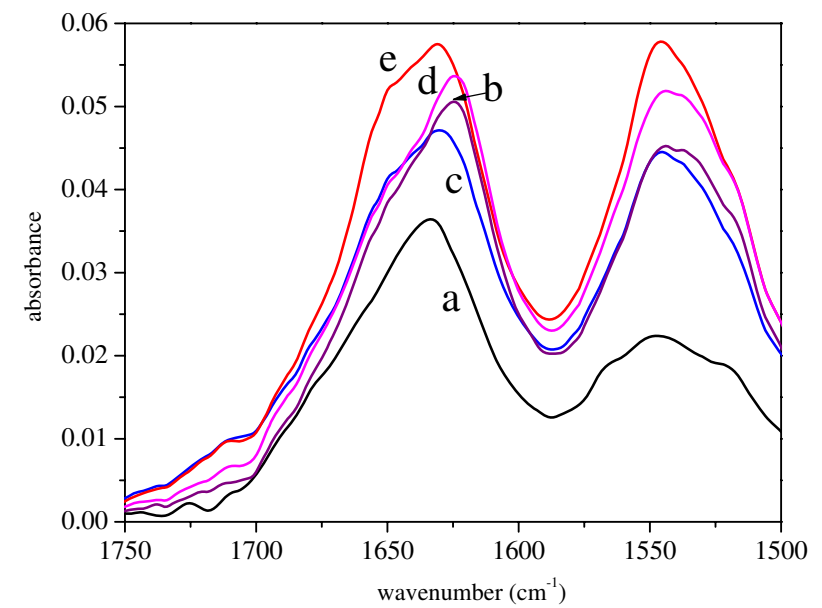

Figure 3

FT-IR spectra in Amide I and Amide II regions of His $7 \Delta \mathrm{N} 6$ TNF- $\alpha$ in solution (a), as ammonium sulfate precipitate (b), and in inclusion bodies isolated from $E$. coli incubated at different temperatures: $25^{\circ} \mathrm{C}$ (c), $37^{\circ} \mathrm{C}$ (d) and $42^{\circ} \mathrm{C}$ (e).

hydrophobic and aggregates at high concentrations. $\Delta$ N19LT- $\alpha$ has a predominant $\beta$-structure that can be seen from the original (Figure 5) and second derivative spectra (Figure 6) of IBs displaying peaks at $1627 \mathrm{~cm}^{-1}$ and 1685 $\mathrm{cm}^{-1}[26,27]$. The infrared spectra of IBs prepared at different growth temperatures differ from each other. Especially prominent is the increase in the intensity of the band at $1650 \mathrm{~cm}^{-1}$ caused by the elevation of the preparation temperature. This change in band intensity implies an increase in the unordered structure inside IBs with respect to those prepared at lower temperatures

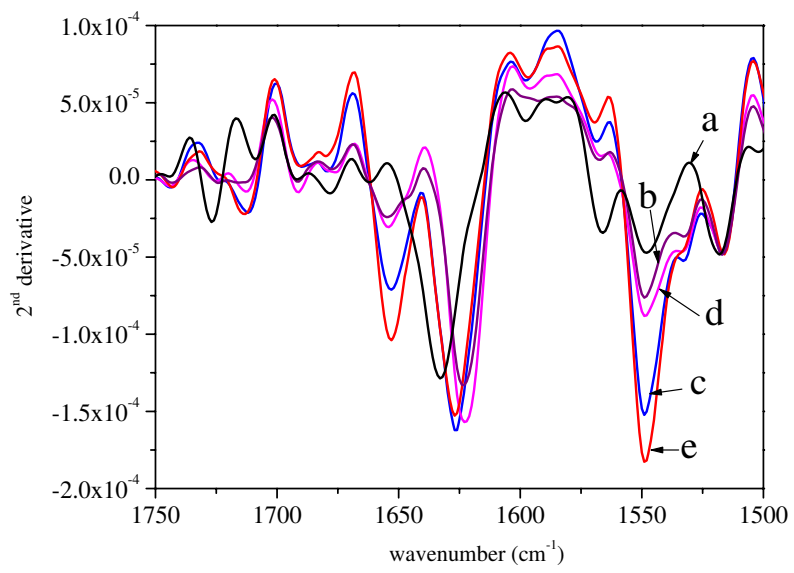

Figure 4

The second derivatives of the spectra presented in Figure 3. 


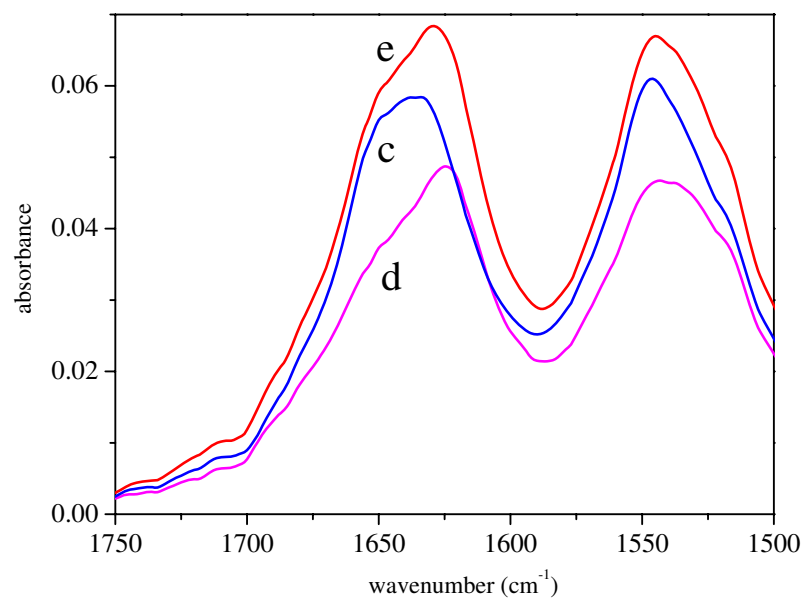

Figure 5

FT-IR spectra in Amide I and Amide II regions of $\Delta$ NI 9 LT- $\alpha$ inclusion bodies isolated from $E$. coli incubated at different temperatures: $25^{\circ} \mathrm{C}(\mathrm{c}), 37^{\circ} \mathrm{C}(\mathrm{d})$ and $42^{\circ} \mathrm{C}(\mathrm{e})$.

\section{Extractability of proteins from IBs}

As already described by Jevsevar [12] and Peternel [11,29], G-CSF IBs prepared at $25^{\circ} \mathrm{C}$ are readily soluble in $0.2 \% \mathrm{~N}$ lauroyl sarcosine with almost $97 \%$ of G-CSF being dissolved. Slightly less protein can be extracted from GFP IBs and His7dN6 TNF- $\alpha$ IBs $(80-85 \%)$ (Figure 7$)$. These proteins, easily extractable from ncIBs, contain a higher percentage of correctly folded protein inside IBs (based on spectroscopy analysis). This supports the hypothesis suggested by Jevsevar at. al. [12] that the more alike the inner structure of the IBs are the easier it is to extract the correctly folded protein from IBs.

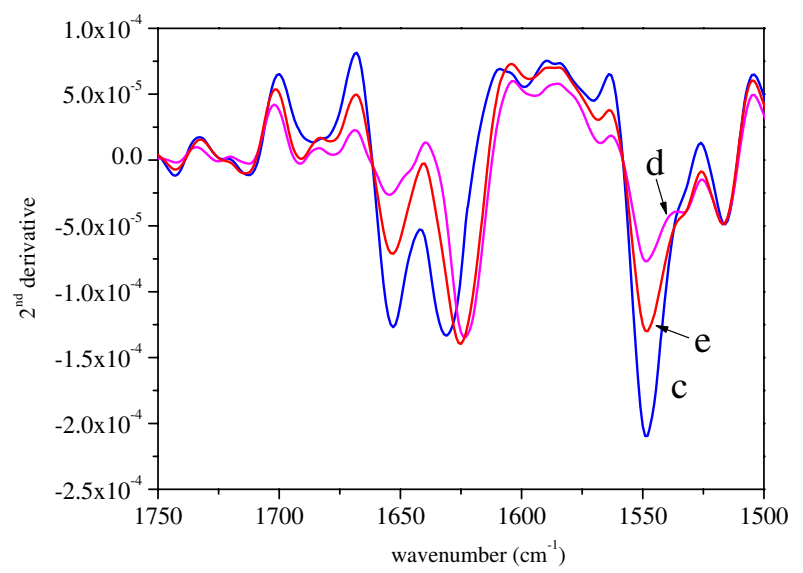

\section{Figure 6}

The second derivatives of the spectra presented in Figure 5.

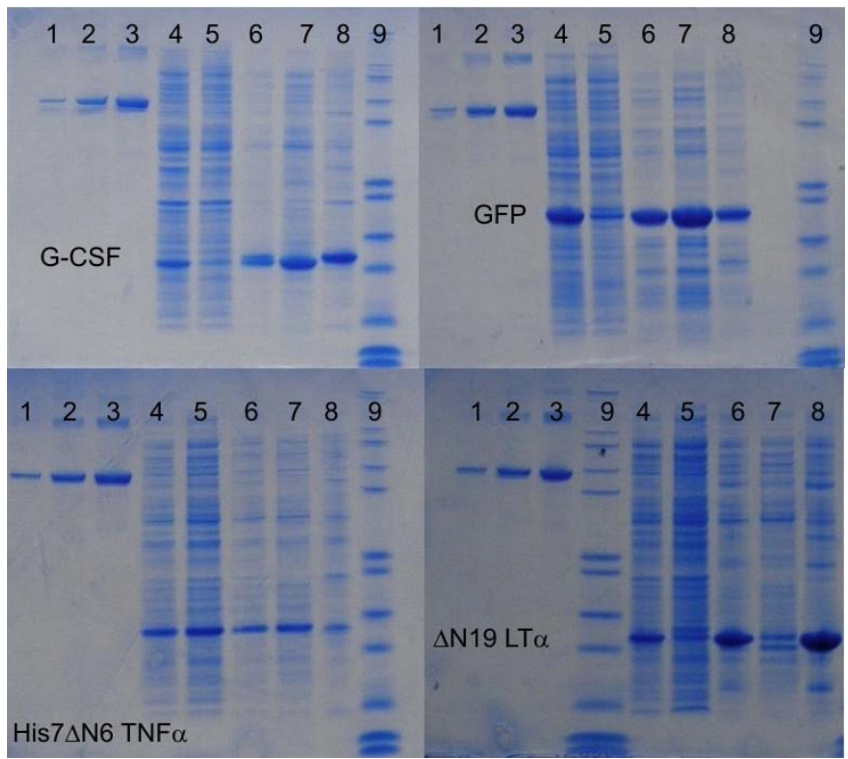

\section{Figure 7}

SDS-PAGE analysis of proteins extracted from IBs with $0.2 \% \mathrm{~N}$-lauroyl sarcosine. Inclusion bodies were isolated from $E$. coli cultivated at $25^{\circ} \mathrm{C}$. I - BSA (Bovine serum albumin) standard $0.2 \mathrm{mg} ; 2$ - BSA standard $0.88 \mathrm{mg} ; 3$ - BSA standard I.5 mg; 4 - total cell proteins; 5 - soluble (cytoplasmic) proteins; 6 - IBs proteins; 7 - IBs proteins extracted with $0.2 \%$ NLS; 8 - in $0.2 \%$ NLS insoluble IBs proteins; 9 LMW standard.

On the other hand, the extractability of $\Delta$ N19LT- $\alpha$ from IBs with $0.2 \% \mathrm{~N}$-lauroyl sarcosine is significantly lower, and only up to $40 \%$ of the target protein can be dissolved (Figure 7). As can be seen from the infrared studies, the percentage of unordered structures inside $\Delta$ N19LT- $\alpha$ IBs is very high (even those formed at $25^{\circ} \mathrm{C}$ ) and this could explain the poor extractability of $\Delta \mathrm{N} 19 \mathrm{LT}-\alpha$ from such IBs.

In all cases, IBs prepared at higher temperatures $\left(37^{\circ} \mathrm{C}\right.$, $42^{\circ} \mathrm{C}$ ) are less soluble in $0.2 \% \mathrm{~N}$-lauroyl sarcosine. The lower solubility of IBs prepared at higher temperatures is not surprising as IBs have been generally reported to be insoluble in mild detergents. This is probably due to the high percentage of unordered protein structures in the IBs that was also confirmed by spectroscopy analysis.

Extractability of properly folded proteins from IBs in mild detergents is a very interesting property. IBs are predominantly composed of the target protein. During protein extraction in mild, non-denaturing conditions mainly properly folded proteins are extracted. We might thus speculate that during such extraction the target protein is further enriched and therefore less downstream steps are necessary to purify the protein. This hypothesis was confirmed during the preparation of the process for purifica- 
tion of G-CSF, where, in a single chromatography step, the production of a biologically active G-CSF with a purity greater than $95 \%$ was achieved [30]. The same was also achieved for the isolation of pure, biologically active, fluorescent GFP and His7dN6 TNF- $\alpha$ (unpublished results).

Here some interesting questions arise, such as whether the IBs of other proteins produced at low temperatures are also in the form of more soluble material containing easily extractable, correctly folded proteins. Since IBs usually represent a highly concentrated pool of the target protein, it is worth exploring the industrial potential of easily soluble IBs, especially those containing large amounts of biologically active protein, in order to reduce production costs and to develop environmentally less harmful technologies. Such IBs composed of pure protein could also be used as active nanoparticles in diagnostics or as biocatalysts in enzymatic processes or even as biopharmaceuticals.

\section{Biological activity}

The specific biological activity of the protein was measured in two distinctive fractions: soluble protein produced in the cytoplasm (SN1) and insoluble protein, solubilized from IBs under mild non-denaturing conditions in $0.2 \%$ N-lauroyl sarcosine (SN2). Biological activity was measured for all four studied proteins.
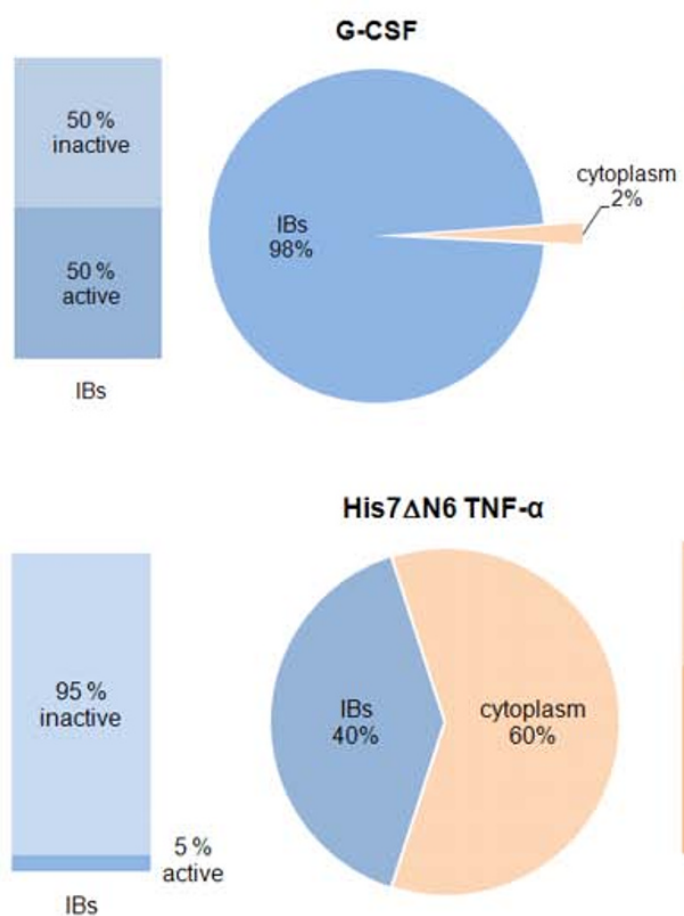

IBs

\section{Figure 8}

Distribution of target protein between the soluble fraction (cytoplasm) and insoluble fraction (IBs) is presented on pie diagrams. Percentages of specific biological activity of target proteins in each fraction are presented on column charts.

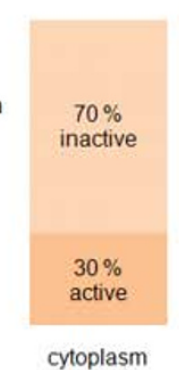

Almost 50\% of G-CSF extracted from the IBs shows specific biological activity [11]. Since the majority of the expressed G-CSF is in the form of IBs $(98 \%)$, this represents almost all the biologically active protein produced in the cell. From the remaining $2 \%$ of total GCSF, which is produced in the cytoplasm, only $30 \%$ is in active form, representing less than $1 \%$ of the total G-CSF (Table 2, Figure 8).

Altogether around $12 \%$ of the total GFP produced in bacterial cells is correctly folded and oxidized (fluorescent). As previously reported by Garcia-Fruitos at al. [10], GFP inside the IBs can be highly fluorescent. Our results show that $6 \%$ of all GFP in IBs is in the active, fluorescent form. Although the amount of active, fluorescent GFP in the cytoplasm is higher (about $30 \%$ ), the protein is predominantly produced in the insoluble fraction (77\%). Therefore, the share of the total GFP produced in the cell is almost equally distributed between the soluble and insoluble fraction (Table 2, Figure 8). Based on the spectroscopy analysis, we believe that the amount of correctly folded protein inside IBs is even higher, but not all the correctly folded protein is oxidized. Consequently not all the correctly folded protein is fluorescent.

As in the case of GFP, around $5 \%$ of His7 $\triangle \mathrm{N} 6$ TNF- $\alpha$ extracted from IBs is in biologically active form. Since
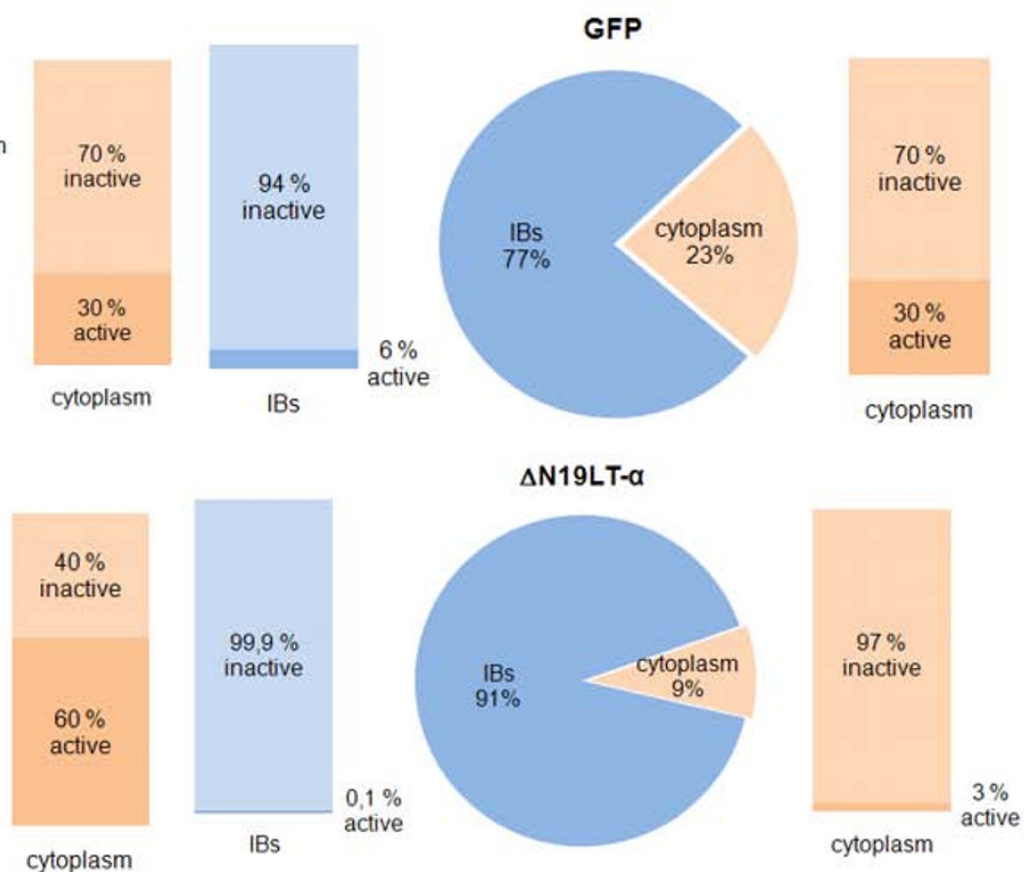
Table 2: Specific biological activity of the target protein regarding the total target protein produced in bacterial cell is presented. The distribution between soluble (cytoplasm) and insoluble (IBs) cell fraction is also presented.

\begin{tabular}{|c|c|c|c|}
\hline Target protein & $\begin{array}{l}\text { Specific biological activity of the target protein produced in } \\
\text { bacterial cells }\end{array}$ & Distribution between soluble anc & \\
\hline & & cytoplasm & IBs \\
\hline G-CSF & 49,6 & 0,6 & 49 \\
\hline GFP & 12 & 7 & 5 \\
\hline His7 $\Delta$ N6 TNF- $\alpha$ & 38 & 36 & 2 \\
\hline$\Delta \mathrm{N} / 9 \mathrm{LT}-\alpha$ & 0,4 & 0,3 & 0,1 \\
\hline
\end{tabular}

$40 \%$ of the protein is produced inside IBs, this represents $2 \%$ of the total His7 $\triangle$ NG TNF- $\alpha$ produced in E. coli. Protein produced in the cytoplasm shows much higher biological activity (around 60\%) and this corresponds to $36 \%$ of the total His $7 \Delta \mathrm{N} 6$ TNF- $\alpha$ produced in the cell. Therefore we can conclude that correctly folded His $7 \Delta \mathrm{N} 6$ TNF- $\alpha$ is predominantly produced in the soluble fraction (Table 2, Figure 8).

The specific biological activity of total $\Delta$ N19LT- $\alpha$ produced in bacterial cells is less than half the percentage of that expected. The protein is mainly produced in the form of IBs inside bacterial cells (91\%). Since only $0.1 \%$ (Table 2 , Figure 8 ) of the protein extracted from IBs is biologically active, we may conclude that IBs of dN19LT- $\alpha$, even when produced at $25^{\circ} \mathrm{C}$, show typical characteristics of classical inclusion bodies containing essentially denatured and almost completely biologically inactive protein. The results were also confirmed by infrared spectroscopy (Figure 5 and 6), which revealed a high percentage of unordered structure in $\Delta$ N19 LT- $\alpha$ IBs produced at low temperature. Some specific biological activity was measured in the soluble protein fraction (3\%), but even there the amount of properly folded protein is very small.

Based on the results presented above, the properly folded active protein can be produced inside the soluble (cytoplasm) and insoluble (IBs) cell fraction. The amount of properly folded protein inside individual cell fractions depends very much on the protein.

In the case of G-CSF, the active protein was predominantly produced inside the IBs. In addition, the amount of active protein inside GFP and His7 $\Delta$ N6 TNF- $\alpha$ IBs was significant and IBs could be used the source for the extraction of active protein. In the case of N19 LT- $\alpha$, the amount of properly folded protein inside IBs was trivial. Therefore we can conclude that three of the four studied proteins form IBs composed of a significant amount of properly folded biologically active protein. As mentioned in a previous section, such IBs containing active proteins are very interesting for research and medical purposes, as well as for industrial use.
Once again it has to be stressed that specific biological activity data discussed above were obtained for IBs prepared at $25^{\circ} \mathrm{C}$. When produced at higher temperatures $\left(37^{\circ} \mathrm{C}, 42^{\circ} \mathrm{C}\right)$, all the proteins showed almost no biological activity. The same results were also obtained by infrared spectroscopy, where spectra of IBs produced at low temperatures were very similar to the spectra of the pure proteins, whereas IBs produced at higher temperatures contain a high proportion of unordered structures.

\section{Conclusion}

In all cases studied so far, it was found that various amounts of correctly folded proteins were trapped inside inclusion bodies. The amount of correctly folded proteins and the solubility of the inclusion bodies mainly depend on the nature of the target protein, as well as on the growth conditions, such as the temperature and induction regime. Infrared spectroscopy analysis shows the presence of correctly folded proteins inside IBs. However, it is not possible to predict the biological activity of the target protein from spectroscopy analysis of the secondary protein structure. Results show that even though spectroscopy analysis shows a relatively high proportion of correctly folded proteins inside IBs (in the case of GFP and His7 $\Delta \mathrm{N} 6 \mathrm{TNF}-\alpha$ at $37^{\circ} \mathrm{C}$ ), very low solubility of IBs in $0.2 \% \mathrm{~N}$-lauroyl sarcosine as well as almost no biological activity can also be observed.

In our future work, we plan to optimize important parameters for the biosynthesis of proteins in the form of inclusion bodies with the main goal of increasing the accumulation of active protein inside the inclusion bodies. This should enable efficient isolation of the active protein by gentle extraction under non-denaturing conditions or even allow the use of IBs as active nanoparticles.

\section{Authors' contributions}

ŠP designed and performed most of the experiments and prepared the manuscript as well as final data analysis and figures. JG performed infrared studies and contributed the expertise on infrared analysis. VGP and RK were consolidating authors and participated in the manuscript preparation. All authors approved the final manuscript. 


\section{Acknowledgements}

The study was financially supported by a Young Researcher's grant (Š.P.) as well as by the research Project "Micro and Nano Particles in Biotechnology" from the Ministry of Higher Education, Science and Technology of Slovenia.

We would like to dedicate this work to Dr. Viktor Menart who played a crucial role in initiating this work.

\section{References}

I. Strandberg L, Enfors SO: Factors influencing inclusion body formation in the production of a fused protein in Escherichia coli. Appl Environ Microbiol 1991, 57:1669-1674.

2. Sorensen HP, Mortensen KK: Soluble expression of recombinant proteins in the cytoplasm of Escherichia coli. Microb Cell Fact 2005, 4:I.

3. De Marco A, Vigh L, Diamant S, Goloubinoff P: Native folding of aggregation-prone recombinant proteins in Escherichia coli by osmolytes, plasmid- or benzyl alcohol-overexpressed molecular chaperones. Cell Stress Chaperones 2005, 10:329-339.

4. Mogk A, Deuerling E, Vorderwulbecke S, Vierling E, Bukau B: Small heat shock proteins, ClpB and the DnaK system form a functional triade in reversing protein aggregation. Mol Microbiol 2003, 50:585-595.

5. Rinas U, Tsai LB, Lyons D, Fox GM, Stearns G, Fieschko J, et al:: Cysteine to serine substitutions in basic fibroblast growth factor: effect on inclusion body formation and proteolytic susceptibility during in vitro refolding. Biotechnology (N Y) 1992, 10:435-440.

6. De MV, Stier G, Blandin S, De Marco A: The solubility and stability of recombinant proteins are increased by their fusion to NusA. Biochem Biophys Res Commun 2004, 322:766-771.

7. Worrall DM, Goss NH: The formation of biologically active beta-galactosidase inclusion bodies in Escherichia coli. Aust J Biotechnol 1989, 3:28-32.

8. Tokatlidis K, Dhurjati P, Millet J, Beguin P, Aubert JP: High activity of inclusion bodies formed in Escherichia coli overproducing Clostridium thermocellum endoglucanase D. FEBS Lett I99I, 282:205-208.

9. Garcia-Fruitos E, Carrio MM, Aris A, Villaverde A: Folding of a misfolding-prone beta-galactosidase in absence of DnaK. Biotechnol Bioeng 2005, 90:869-875.

10. Garcia-Fruitos E, Gonzalez-Montalban N, Morell M, Vera A, Ferraz RM, Aris A, et al.: Aggregation as bacterial inclusion bodies does not imply inactivation of enzymes and fluorescent proteins. Microb Cell Fact 2005, 4:27.

II. Peternel S, Jevsevar S, Bele M, Gaberc-Porekar V, Menart V: New properties of inclusion bodies with implications for biotechnology. Biotechnol Appl Biochem 2008, 49:239-246.

12. Jevsevar S, Gaberc-Porekar V, Fonda I, Podobnik B, Grdadolnik J, Menart V: Production of nonclassical inclusion bodies from which correctly folded protein can be extracted. Biotechnol Prog 2005, 21:632-639.

13. Ami D, Natalello A, Taylor G, Tonon G, Maria DS: Structural analysis of protein inclusion bodies by Fourier transform infrared microspectroscopy. Biochim Biophys Acta 2006, I 764:793-799.

14. Oberg K, Chrunyk BA, Wetzel R, Fink AL: Nativelike secondary structure in interleukin-I beta inclusion bodies by attenuated total reflectance FTIR. Biochemistry 1994, 33:2628-2634.

15. Ami D, Natalello A, Gatti-Lafranconi P, Lotti M, Doglia SM: Kinetics of inclusion body formation studied in intact cells by FT-IR spectroscopy. FEBS Lett 2005, 579:3433-3436.

16. Vera A, Gonzalez-Montalban N, Aris A, Villaverde A: The conformational quality of insoluble recombinant proteins is enhanced at low growth temperatures. Biotechnol Bioeng 2007, 96:110I-1106.

17. Doglia SM, Ami D, Natalello A, Gatti-Lafranconi P, Lotti M: Fourier transform infrared spectroscopy analysis of the conformational quality of recombinant proteins within inclusion bodies. Biotechnol ] 2008, 3:193-201.

18. Kenig M, Peternel S, Gaberc-Porekar V, Menart V: Influence of the protein oligomericity on final yield after affinity tag removal in purification of recombinant proteins. J Chromatogr A 2006, I I 01:293-306.
19. Hammerling $U$, Kroon R, Sjodin L: In vitro bioassay with enhanced sensitivity for human granulocyte colony-stimulating factor. J Pharm Biomed Anal 1995, 13:9-20.

20. Fonda I, Pernus M, Gaberc-Porekar V, Kenig M, Stalc A, Meager A, et al.: Improvement of potential therapeutic value of tumor necrosis-alpha (TNF-alpha) by charge modulation in the tip region. Eur Cytokine Netw 2005, 16:17-26.

21. Flick DA, Gifford GE: Comparison of in vitro cell cytotoxic assays for tumor necrosis factor. I Immunol Methods 1984, 68:167-175.

22. Ventura $S$, Villaverde A: Protein quality in bacterial inclusion bodies. Trends Biotechnol 2006, 24:179-185.

23. Sim J, Sim TS: Amino acid substitutions affecting protein solubility: high level expression of Streptomyces clavuligerus isopenicillin $\mathbf{N}$ synthase in Escherichia coli. J Mol Catal B 1999, 6:133-143.

24. KRIMM S: Infrared spectra and chain conformation of proteins. J Mol Biol 1962, 4:528-540.

25. Grdadolnik J, Marechal Y: Bovine serum albumin observed by infrared spectrometry. II. Hydration mechanisms and interaction configurations of embedded $\mathrm{H}(2) \mathrm{O}$ molecules. Biopolymers 200I, 62:54-67.

26. Fabian H, Mäntele W: Infrared Spectroscopy of Proteins. Handbook of vibrational spectroscopy: Applications in Life, Pharmaceutical and Natural Sciences. Wiley 2001:3399-3425.

27. Bandekar J, KRIMM S: Normal mode of the spectrum of the parallel-chain beta-sheet. Biopolymers 1988, 27:909-921.

28. Jackson M, Mantsch HH: The use and misuse of FTIR spectroscopy in the determination of protein structure. Crit Rev Biochem Mol Biol 1995, 30:95-I20.

29. Peternel S, Bele M, Gaberc-Porekar V, Komel R: Contraction of inclusion bodies with implications in biotechnology. Acta Chim Slov 2008, 55:608-6I2.

30. Gaberc Porekar V, Menart V: Process for the Purification And/ Or Isolation Of Biologically Active Granulocyte Colony Stimulating Factor. PCT/EPO2//38/O[WO 03/05/922 Al] 2003.

Publish with Bio Med Central and every scientist can read your work free of charge

"BioMed Central will be the most significant development for disseminating the results of biomedical research in our lifetime. "

Sir Paul Nurse, Cancer Research UK

Your research papers will be:

- available free of charge to the entire biomedical community

- peer reviewed and published immediately upon acceptance

- cited in PubMed and archived on PubMed Central

- yours - you keep the copyright 